WellBeing International

WBI Studies Repository

$12-1982$

\title{
Aquatic Feeding by Moose: Seasonal Variation in Relation to Plant Chemical Composition and Use of Mineral Licks
}

D. Fraser

Ontario Ministry of Natural Resources

B. K. Thompson

Agriculture Canada

D. Arthur

University of Guelph

Follow this and additional works at: https://www.wellbeingintlstudiesrepository.org/feebeh

Part of the Animal Studies Commons, Behavior and Ethology Commons, and the Comparative Psychology Commons

\section{Recommended Citation}

Fraser, D., Thompson, B. K., \& Arthur, D. (1982). Aquatic feeding by moose: seasonal variation in relation to plant chemical composition and use of mineral licks. Canadian Journal of Zoology, 60(12), 3121-3126.

This material is brought to you for free and open access by WellBeing International. It has been accepted for inclusion by an authorized administrator of the WBI Studies Repository. For more information, please contact wbisr-info@wellbeingintl.org.

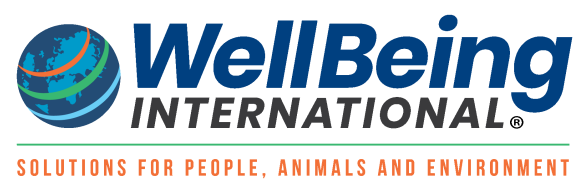




\title{
Aquatic Feeding by Moose: Seasonal Variation in Relation to Plant Chemical Composition and Use of Mineral Licks
}

\author{
D. Fraser $^{1}$, B.K. Thompson ${ }^{2}$ and D. Arthur ${ }^{3}$ \\ ${ }^{1}$ Ontario Ministry of Natural Resources \\ ${ }^{2}$ Agriculture Canada \\ ${ }^{3}$ University of Guelph
}

\begin{abstract}
Activity of moose (Alces alces) was studied at aquatic feeding areas and at natural, sodium-rich licks during four periods covering late May to early September. Aquatic feeding increased from period 1 (late May and early June) to period 2 (late June and early July) and had declined by late July. Major activity at mineral licks occurred earlier in the season than aquatic feeding, especially for males. Chemical composition of aquatic plants showed no seasonal changes corresponding to the peak of aquatic feeding in period 2, although the sodium content of some species declined in period 3. We suggest that moose in the study area are attracted to sodium sources from late May to mid-July, that aquatic feeding replaces use of licks in June as the most sodium-rich aquatic plants become abundant, and that both activities decrease in midsummer because of declining attraction to sodium.
\end{abstract}

Aquatic feeding by moose shows some striking and potentially instructive seasonal variation. In most areas, aquatic feeding becomes common in the spring or early summer, and then decreases sharply near the end of July (e.g., Cobus 1972). This decrease has generally been attributed to declining palatability of aquatic vegetation (Peterson 1955). However, Jordan et al. (1973) suggest that moose use aquatic plants mainly as a source of sodium ( $\mathrm{Na}$ ). If this is true, then the common midsummer decline in aquatic feeding may reflect a change in the plants' $\mathrm{Na}$ content or in the animals' requirements for $\mathrm{Na}$.

In this study we documented the seasonal pattern of aquatic feeding by moose in an area of Ontario. To explore possible causes for the seasonal pattern, we also studied changes in the chemical composition of aquatic plants and changes in moose activity at two natural Na-rich springs.

\section{STUDY AREA}

The study was done in Sibley Provincial Park, Ontario, a 243- $\mathrm{km}^{2}$ area on a peninsula on the north shore of Lake Superior $\left(48^{\circ} 25^{\prime} \mathrm{N}, 88^{\circ} 47^{\prime} \mathrm{W}\right)$. The forest is principally boreal as described by Rowe (1972). The park supports conspicious populations of moose, white-tailed deer (Odocoileus virginianus), and black bears (Ursus americanus). The five lakes used for aquatic feeding observations range in size from 2 to 66 ha with depth no greater than $2 \mathrm{~m}$, and total alkalinity of 65 to $105 \mathrm{ppm} \mathrm{CaCO}_{3}$. The mineral licks are 
described by Fraser and Hristienko (1981) and Fraser and Reardon (1980). Leaf flush of trembling aspen (Populus tremuloides), as an indicator of spring phenology of major browse species, occurred about 14 May in 1976 and about 7 May in 1977 based on the criteria of Stewart et al. (1977).

\section{METHODS}

A previous study in the same area (Cobus 1972) had shown that aquatic feeding was most common roughly between mid-June and mid-July. The present study included four periods of observation: (1) 22 May - 5 June, (2) 19 June - 8 July, (3) 19 July - 4 August, and (4) 13 August - 5 September. These were designed to occur before, during, after, and well after the peak of aquatic feeding, respectively.

Observations were made on four lakes (Joeboy, Lizard, Grassy, and 24A) in 1976, and on Gardner Lake in 1977. Eight 3-h shifts were scheduled for each lake during each of the four periods of the summer. At each lake, half of the shifts were between 0600 and 0900 and half between 1800 and 2100 ( $\pm 30 \mathrm{~min}$ ), times shown to include the greatest amount of aquatic feeding activity (Bouchard 1967; Cobus 1972). Of the 160 scheduled shifts, 16 were not completed because of poor weather or other reasons.

Throughout each 3-h shift, an observer with binoculars, stationed in a canoe, boat, or fixed shoreline location, noted the number of moose present during the shift and recorded time of arrival and departure, location, behaviour, age-class, sex, and appearance of the moose when possible. Animals were classed according to age (calf, yearling, or adult) mainly on the basis of body and antler size. However, there was considerable doubt in distinguishing yearlings from adults, especially for females seen at a distance; therefore animals older than calves were combined in the analysis.

In Joeboy and Gardner lakes, the large numbers of moose made it difficult to record exact times of arrival and departure for all animals. These lakes, therefore, were scanned at 15-min intervals throughout each 3-h shift for a total of 13 scans per shift. The number of adult moose (yearling and older) present in each scan were then added to give a score for the shift. To make results from the other lakes comparable, the number of moose present at 15-min intervals was determined from the detailed records, and scores per shift were calculated in the same manner as for Joeboy and Gardner lakes.

Aquatic plants were collected for chemical analysis in 1976 from the four lakes used for observation of aquatic feeding in that year (Joeboy, Lizard, Grassy, and 24A), and from two other convenient lakes. Of these, only Joeboy was heavily used by moose. In each of the four observation periods, 14 species of plants were collected from one to five lakes each, for a total of 28 samples collected in each period. The species selected were those judged sufficiently abundant to be collected during the first period of the summer when some late-developing species were not yet plentiful. Each sample consisted of about $1 \mathrm{~kg}$ of wet material composed, when possible, of plants taken from several parts of the lake.

Plant parts were collected in a manner that simulated removal by moose as much as our knowledge allowed. Most plants were pulled by the stem or petiole near the water surface, and adhering roots, leaves, flowers, and fruit were included. Roots generally remained attached only with Myriophyllum exalbescens, Eleocharis acicularis, and Sparganium angustifolium, and were deliberately removed from the last species since moose had been seen to avoid roots when feeding on this plant. Typha latifolia were gripped firmly and pulled straight up, yielding the inner leaves and white base of the stem, but leaving the root stock behind.

Plants were sorted by species on the day of collection and rinsed several times in lake water until the water remained clear. Rinsed plants were air-dried in the field and oven-dried in the laboratory $\left(135^{\circ} \mathrm{C}\right.$ for $2 \mathrm{~h}$ ). They were analysed for major cations ( $\mathrm{Na}, \mathrm{K}, \mathrm{Ca}$, and $\mathrm{Mg}$ ), for Fe in view of the high levels of Fe reported in a preferred aquatic feeding area (Fraser et al. 1980), and for $\mathrm{SO}_{4}$ because of the hypothesis 
of Hanson and Jones (1976) that ungulates may be attracted to sources of sulphur. Analyses followed the methods of Gerritz (1935) and the Perkin-Elmer Corporation (Anonymous 1973). Ten of the 28 sets of samples were also analysed for crude protein (CP), crude fibre (CF), and ether extract (EE) according to standard methods of the AOAC (Anonymous 1980).

In the 2nd year of fieldwork (1977), a 4-year study was begun of moose activity at two natural mineral springs (licks) in the study area. To provide a direct comparison of lick use and aquatic feeding, most of the 1977 observations at licks were done during the same four periods used for aquatic feeding observations. Between 10 and 21, 3-h shifts were scheduled at each of the two licks in each of the four periods. The study is described by Fraser and Hristienko (1981).

\section{RESULTS AND DISCUSSION}

Aquatic feeding

There were 167 sightings of yearling and older moose of known sex in the water. In addition there were 15 sightings of calves, 13 sightings of moose whose sex could not be determined, and 21 other sightings that were omitted from analysis because the animals were not seen in the water.

FIG. 1. Mean aquatic feeding score per 3-h observation shift for male $(\bullet)$ and female $(O)$ moose in Joeboy Lake, Gardner Lake, and the three other lakes during the four periods of the summer. The periods were (1) 22 May - 5 June, (2) 19 June - 8 July, (3) 19 July - 4 August, and (4) 13 August - 5 September.

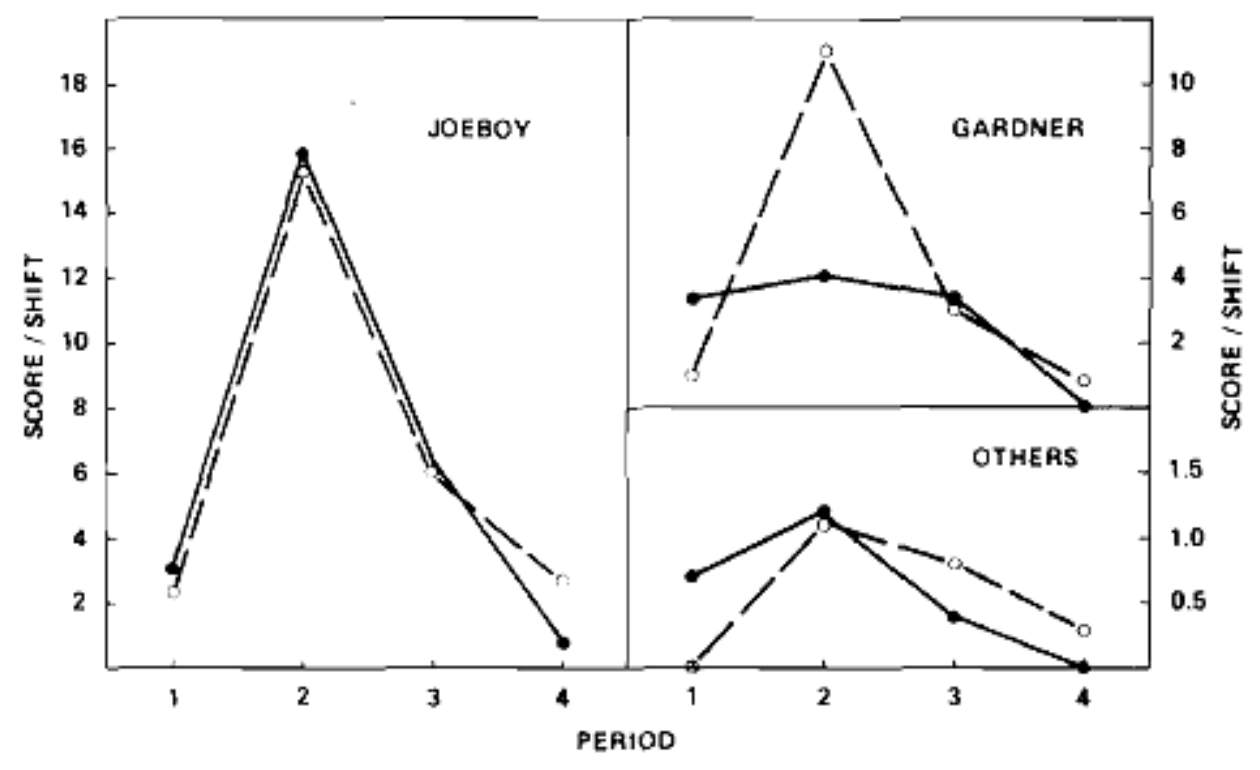

As expected on the basis of previous studies, moose were seen most often in period 2, with less activity earlier and later in the season (Fig. 1). This was true of both sexes and all lakes, although there was greater variation in the lakes with fewest sightings. Because of the skewed frequency distribution of sightings, each 3-h shift was classed as having no moose, one moose, or more than one moose seen, and the data were analyzed as multiway contingency tables (Fienberg 1970). This analysis showed large differences between lakes $(P<0.001)$ and between periods $(P<0.001)$, and there were slightly more sightings in evening than in morning shifts $(0.10>P>0.05)$. Interactions between these factors were nonsignificant. 
TABLE 1. Species of aquatic plants collected, number of lakes from which each species was collected, and chemical composition expressed as percentage of dry matter, averaged over the four periods. Plant species are listed in order of decreasing $\mathrm{Na}$ content. Means are based on one sample in each of four periods for each lake and species.

\begin{tabular}{|lcccccccccc|}
\hline Species & Lakes & $\mathbf{N a}$ & $\mathbf{K}$ & $\mathbf{C a}$ & $\mathbf{M g}$ & $\mathbf{F e}$ & $\mathbf{S O}_{4}$ & $\mathbf{C P}$ & $\mathbf{C F}$ & $\mathbf{E E}$ \\
\hline Utricularia vulgaris & 2 & 1.39 & 1.67 & 1.06 & 0.76 & 0.41 & 0.94 & --- & --- & --- \\
Sparganium angustifolium & 1 & 0.60 & 2.42 & 1.01 & 0.47 & 0.25 & 1.06 & --- & --- & --- \\
Myriophyllum exalbescens & 1 & 0.60 & 1.45 & 1.33 & 0.23 & 0.26 & 0.97 & 13.8 & 16.7 & 0.9 \\
Potamogeton epihydrus & 1 & 0.57 & 3.12 & 1.16 & 0.40 & 0.27 & 1.70 & --- & --- & --- \\
P. gramineus & 1 & 0.55 & 2.45 & 1.22 & 0.35 & 0.24 & 1.33 & 13.3 & 23.9 & 2.0 \\
$P$. jiliformis & 2 & 0.49 & 1.46 & 1.38 & 0.32 & 0.18 & 1.05 & --- & --- & --- \\
Nuphar variegatum & 5 & 0.44 & 1.88 & 1.12 & 0.25 & 0.04 & 0.69 & --- & --- & --- \\
$P$. natans & 1 & 0.31 & 1.48 & 1.02 & 0.49 & 0.22 & 0.93 & 10.5 & 28.8 & 2.9 \\
$P$. amplifolius & $4 *$ & 0.22 & 2.18 & 2.56 & 0.30 & 0.14 & 0.75 & 12.2 & 25.0 & 1.4 \\
Eleocharis acicularis & 1 & 0.19 & 0.99 & 0.88 & 0.35 & 0.74 & 1.31 & 10.1 & 21.4 & 2.3 \\
P. praelongus & 3 & 0.10 & 1.89 & 1.45 & 0.30 & 0.07 & 0.58 & 13.8 & 25.2 & 2.3 \\
Typha latifolia & 1 & 0.09 & 2.03 & 1.08 & 0.33 & 0.01 & 0.52 & --- & --- & --- \\
Characeae & 3 & 0.05 & 0.73 & 11.88 & 0.66 & 0.17 & 1.19 & --- & --- & --- \\
Equisetum juviatile & 2 & 0.04 & 2.09 & 1.24 & 0.48 & 0.05 & 1.42 & --- & --- & --- \\
Standard deviation $\dagger$ & & 0.18 & 0.41 & 1.88 & 0.11 & 0.12 & 0.26 & 1.80 & 3.35 & 0.66 \\
\hline
\end{tabular}

*Only three samples analyzed for CP, CF, and EE.

†Based on the error mean square from the analysis of variance with $26 \mathrm{df}$ for CP, CF, and EE, and $46 \mathrm{df}$ for the other chemical components.

There were more sightings of males than of females in period 1, and vice versa in period 4 (Fig. 1). This trend was confirmed by chi-square analysis of sightings classed according to sex (calves excluded) which showed a period $\times$ sex interaction $(P<0.05)$. Similarly, Cobus $(1972)$ and Fraser et al. $(1980)$ noted that males predominated in aquatic feeding early in the season.

Length of feeding episodes, estimated as the number of scans in which each animal was seen, was shortest in period 1 for Joeboy and Gardner lakes (mean of 2.3 scans /sighting) and then increased to $4.3,5.2$, and 3.8 scans/sighting in periods 2 to 4 respectively. Analysis of variance showed that the number of scans per sighting varied among periods $(P<0.01)$, mainly because of a difference between period 1 and the others $(P<0.01)$. Also, visits were shorter at the two smallest lakes, 24A and Grassy $(P$ $<0.05$ ); perhaps some moose left the small lakes prematurely because of the closer presence of the observer.

\section{Plant chemical composition}

There were large differences among species in chemical composition, and some systematic seasonal trends and differences between lakes. However, no chemical component had particularly high or low levels in period 2, corresponding to the peak of aquatic feeding by moose.

The results were treated by three-way analysis of variance for plant species, lake, and period. In the case of CP, CF, and EE, the analysis of lakes and species effects was restricted to four lakes and four plant species because the remaining species were analyzed for only one lake each. The analysis showed significant differences between plant species in $\mathrm{Na}, \mathrm{K}, \mathrm{Ca}, \mathrm{Mg}, \mathrm{Fe}$, and $\mathrm{SO}_{4}(P<0.001)$, and in $\mathrm{CF}$ and EE $(P<0.01)$, but not in CP $(P>0.05)$. Differences among plant species are summarized in Table 1. 
There were large differences between periods (shown in Fig. 2) in $\mathrm{K}$ and $\mathrm{CP}(P<0.001$ ), and smaller differences in $\mathrm{Na}, \mathrm{Fe}$, and $\mathrm{CF}(P<0.05)$. Ca showed no overall seasonal trend, but increased in the case of the leafy pondweeds, $P$. amplifolius and $P$. praelongus, as carbonate deposits developed on the leaves (Fig. 2).

FIG. 2. Chemical composition of aquatic plants, expressed as percent of dry matter, in the four periods of the summer. Values of $\mathrm{Na}, \mathrm{Fe}, \mathrm{CF}, \mathrm{CP}$, and $\mathrm{K}$ are averaged over all species and lakes. Values of $\mathrm{Ca}$ are shown for Potamogeton amplifolius (P.a.) and P. praelongus (P.p.).

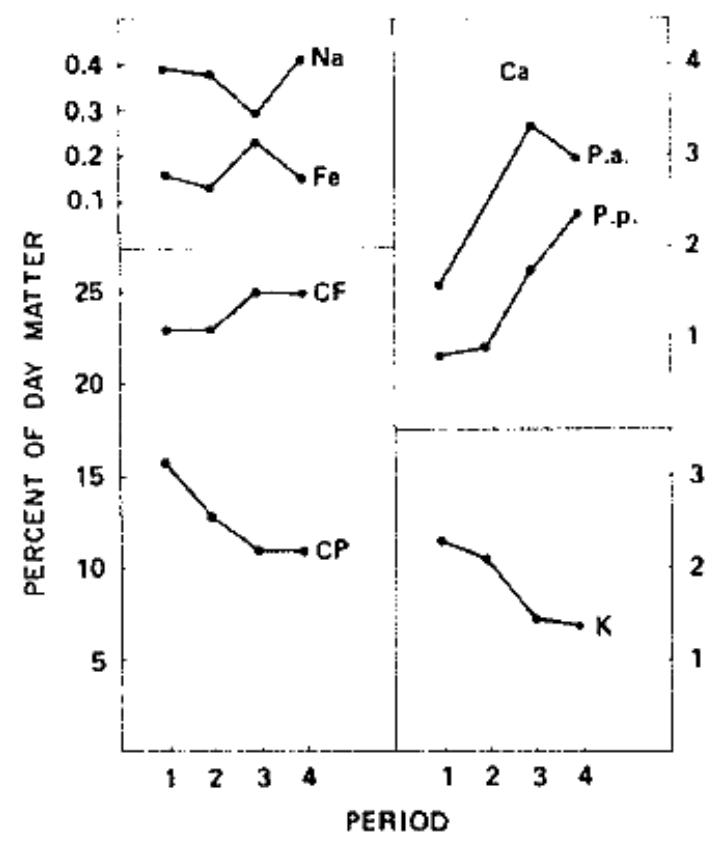

FIG. 3. Mean time (minutes) spent at the Marie Louise and Perry Bay mineral licks per 3-h observation shift, by male $(\bullet)$ and female $(\circ)$ moose during the four periods of the summer.

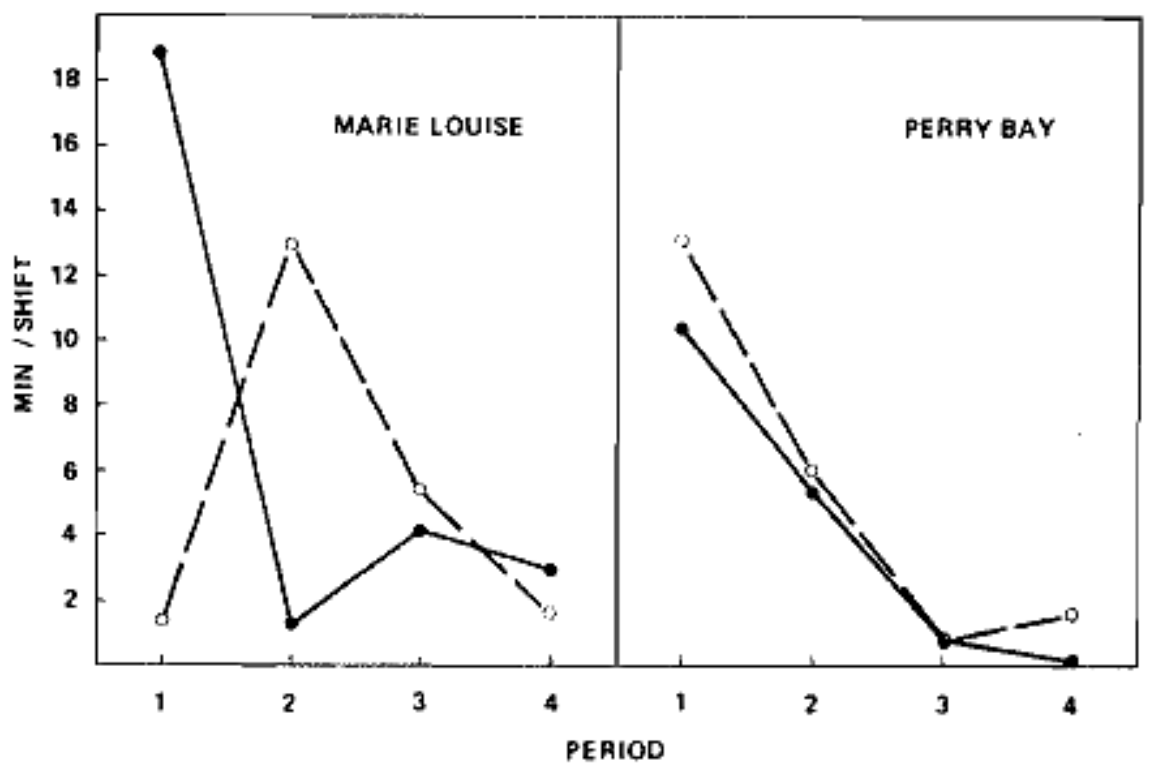


TABLE 2. Na content as percent of dry matter (mean $\pm \mathrm{SE}$ ) and $\mathrm{Na} / \mathrm{K}$ ratio for plant species of high, medium, and low $\mathrm{Na}$ content, during the four periods of the study. Means are based on six, four, and four species in the three categories, respectively.

\begin{tabular}{|cccc|}
\hline & \multicolumn{3}{c|}{ Na content } \\
\cline { 2 - 4 } Period & High & Medium & Low \\
\hline & & Na as $\%$ of dry matter \\
2 & $0.88 \pm 0.14$ & $0.26 \pm 0.07$ & $0.08 \pm 0.01$ \\
3 & $0.78 \pm 0.17$ & $0.28 \pm 0.09$ & $0.05 \pm 0.01$ \\
4 & $0.53 \pm 0.17$ & $0.26 \pm 0.06$ & $0.05 \pm 0.02$ \\
& $0.62 \pm 0.15$ & $0.37 \pm 0.12$ & $0.11 \pm 0.03$ \\
1 & & Na/K ratio & \\
2 & $0.36 \pm 0.07$ & $0.13 \pm 0.02$ & $0.04 \pm 0.01$ \\
3 & $0.38 \pm 0.11$ & $0.13 \pm 0.04$ & $0.04 \pm 0.02$ \\
4 & $0.34 \pm 0.12$ & $0.30 \pm 0.11$ & $0.05 \pm 0.02$ \\
& $0.43 \pm 0.14$ & $0.32 \pm 0.11$ & $0.11 \pm 0.04$ \\
\hline
\end{tabular}

Because moose appear to use the more Na-rich species of aquatics (D. Fraser, unpublished data), plants of high $\mathrm{Na}$ content (first six species in Table 1) were separated from plants of medium (next four species) or low $\mathrm{Na}$ content (last four species) for comparison of seasonal changes. Na levels in the most Na-rich species declined somewhat in period 3 (Table 2). This could possibly reflect selective removal by moose of the most Na-rich plants among the preferred species during the preceding period when feeding was most intense. No similar trend was apparent in the less Na-rich species. The $\mathrm{Na} / \mathrm{K}$ ratio, whose significance is discussed by Weeks and Kirkpatrick (1976), remained approximately constant on average for the Na-rich species, but increased somewhat for the other species in periods 3 and 4 as $\mathrm{K}$ levels declined (Table 2).

Significant differences between lakes were found in Na and CP $(P<0.01)$, and in $\mathrm{Mg}$ and CF $(P<0.05)$. Joeboy Lake had higher levels of $\mathrm{Na}$ than the other lakes $(P<0.01)$, but differences among the other lakes were not significant.

\section{Activity at mineral licks}

Male moose used the mineral licks mainly during period 1 (Fig. 3), with a steady decline thereafter. Males of adult size were not seen in either lick after period 2, the later use involving only small-bodied (mainly yearling) males. Activity by females declined after the first period at the Perry Bay lick, and peaked in the second period at the Marie Louise lick (Fig. 3). Chi-square analysis was done with the 3-h shifts classed as "unsuccessful" if moose were not seen, or "successful" if one or more moose were present. Periods 3 and 4 were combined to reduce the number of low expected values. The proportion of successful shifts differed between periods $(P<0.001)$, but not between licks. Chi-square analysis was also done with each sighting classed according to sex, period, and lick. Significant interactions were found between period and sex $(P<0.01)$ and between period, sex, and lick $(P<0.05)$ reflecting the trends described above.

\section{GENERAL DISCUSSION}

There is a continuing debate on why moose eat aquatic plants. Workers on Isle Royale argue that moose seek aquatics principally as a source of $\mathrm{Na}$ (Jordan et al. 1973; Botkin et al. 1973). In support of this view, our subsequent field studies show that moose generally select the most Na-rich species of aquatic plants (D. Fraser, unpublished data). Traditionally, however, it has been assumed that aquatics are used simply as a seasonal alternative to woody browse, not as a source of any special nutrients. The present study 
does not provide clear arguments for or against either interpretation, but is perhaps more easily explained by the Na hypothesis.

If aquatic plants are not sought as a source of special nutrients, then presumably the timing of aquatic versus terrestrial feeding would be determined partly by the nutritional value and palatability of the vegetation. On this basis, the limited results presented here provide no obvious explanation for the striking seasonal pattern of aquatic feeding. In period 1, as also noted by Cobus (1972), lakes in the study area had a substantial growth of the larger, early-developing species such as Nuphar variegatum, Potamogeton amplifolius, and $P$. praelongus. There was surprisingly little feeding at this time, although low temperatures in the water and lake bottom may have discouraged the animals, and may help to account for the shorter feeding visits in period 1.

The decline in feeding by late July is also puzzling. It is often suggested that aquatics are less palatable by this time (e.g., Peterson 1955), but the present results give only modest support to this view. CF increased only slightly over the season. CP and K decreased steadily, but maintained levels typical of woody browse in the area (D. Fraser, unpublished data). Also, although early-developing species had apparently ceased rapid growth by midsummer, many late-maturing species continued to produce new growth late into the summer. Substantial $\mathrm{Ca}$ accumulations, which might decrease palatability, were detected only on the two large pondweeds.

The data make perhaps a better fit to the $\mathrm{Na}$ hypothesis, but not without some interpretation. Certainly the seasonal pattern of aquatic feeding did not follow any trends in the $\mathrm{Na}$ content or $\mathrm{Na} / \mathrm{K}$ ratios of the plants (Table 2). However, moose in the study area do appear to have a strong attraction to $\mathrm{Na}$ in the spring and early summer. Chemical analysis and a selection experiment at the mineral licks indicate that $\mathrm{Na}$ is the main or only element sought at the licks (Fraser and Reardon 1980). Moose in the area can be baited with $\mathrm{NaCl}$ (D. Fraser, unpublished data) and are attracted to roadside pools with high levels of $\mathrm{Na}$ derived from highway salt (Fraser and Thomas 1982). Moose activity at these various salt sources becomes pronounced usually in late May and June, but declines sharply by late July and August.

Suggested reasons for the seasonal $\mathrm{Na}$ appetite are discussed elsewhere (Fraser and Hristienko 1981). Briefly, the greater succulence and higher $\mathrm{K}$ content of the new vegetation may cause wet feces and a temporary increase in loss of $\mathrm{Na}$ through fecal moisture (Weeks and Kirkpatrick 1976). Also, recovery of body weight in the warm season may require more $\mathrm{Na}$ than woody browse can provide. Presumably these problems are largely rectified part way through, the summer in most cases. Similarly, most other North American work shows that ungulates' attraction to salt is far more conspicuous in the spring and early summer than at other times (e.g., Dalke et al. 1965; Hebert and Cowan 1971; Weeks 1978).

The apparent waning of $\mathrm{Na}$ appetite by late July could explain why aquatic feeding was sparse in periods 3 and 4 . However, it remains to be explained why aquatic feeding reached its peak in period 2 , by which time the moose (males at least) showed declining interest in the mineral licks.

A possible explanation lies in aquatic plant phenology and the difference in Na levels between licks and aquatics. Based on $\mathrm{Na}$ levels reported here, together with wet weights determined in the field, we estimate that the more Na-rich species contained $\mathrm{Na}$ at about 150 to 700ppm of plant material when dripping wet. Presumably, moose could obtain more $\mathrm{Na}$ from the richer aquatics than from mineral spring water with its $\mathrm{Na}$ content of 50-200ppm (Fraser and Hristienko 1981). However, many of the Na-rich species are not plentiful in period 1 , when lick use is at its peak. The early-developing plants typically have low levels of $\mathrm{Na}$ (Potamogeton praelongus and $P$. amplifolius) or moderate levels (Nuphar variegatum). The smaller, more Na-rich pondweeds (e.g., $P$. epihydrus and $P$. gramineus) usually become abundant about mid-June in our study area. 
Based on these observations, we tentatively suggest (i) that moose consumed the more Na-rich aquatics in preference to dilute lick waters, and (ii) that the animals tended to change from lick use to aquatic feeding in June when the more Na-rich plant species became abundant. Some similar observations and arguments have been made by others. Belovsky and Jordan (1981) reason that lick water on Isle Royale is too dilute to compete with aquatics as a source of Na. Tankersley (1981) observed a shift from lick use to aquatic feeding in Alaska. Observations at roadsides also suggest that moose leave relatively dilute mineral water for aquatic feeding. In the Sibley peninsula, where roadside accumulations of salty water rarely exceeded $100 \mathrm{ppm} \mathrm{Na}$, moose generally changed from using salt water to aquatic feeding in mid-

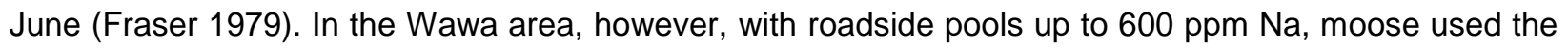
pools throughout the usual aquatic feeding period (Fraser and Thomas 1982).

Like the present study, most work has shown that aquatic feeding decreases by midsummer. The decline is described as occurring in middle or late July (Peterson 1955; Cobus 1972; Fraser et al. 1980) or in early August (F, Dunn, unpublished ${ }^{4}$; Joyal and Scherrer 1978), although de Vos (1958) saw no decline until late August, and Peek et al. (1976) noted increased activity in the autumn. In contrast, moose on Isle Royale apparently continue aquatic feeding from early June to mid-September (Belovsky and Jordan 1981). This protracted feeding appears to result from a depletion of aquatic plants on the island, and may reflect the animals' difficulty in rectifying a $\mathrm{Na}$ imbalance. In most other areas, however, midsummer waning of interest in licks and aquatics may indicate that the animals are coping more easily with any $\mathrm{Na}$ imbalance, and that $\mathrm{Na}$ supplies are likely not as critical for local moose populations as suggested for Isle Royale.

${ }^{4}$ Dunn, F. 1976. Behavioral study of moose. Unpublished report to the Maine Department of Inland Fisheries and Wildlife.

\section{ACKNOWLEDGEMENTS}

We are grateful to Dr. J. K. Morton for checking the plant identifications and for valuable advice, to Ministry of Natural Resources staff in Thunder Bay and Sibley Provincial Park for their kind cooperation, to H. Hristienko, L. Walters, W. Walters, A. Hurley, and K. Chaisson for their assistance in the field, and to C. D. Maclnnes and J. D. Roseborough for support of the project.

\section{REFERENCES}

ANONYMOUS. 1973. Analytical methods for atomic absorption spectrophotometry. Perkin-Elmer Corporation, Norwalk, CT.

ANONYMOUS. 1980. Official methods of analysis, 13th ed. Association of Official Analytical Chemists, Arlington, VA.

BELOVSKY, G. E., and P. A. JORDAN. 1981. Sodium dynamics and adaptations of a moose population. J. Mammal. 62: 613-621.

BOTKIN, D. B., P. A. JORDAN, A. S. DOMINSKI, H. S. LOWENDORF, and G. E. HUTCHISON. 1973. Sodium dynamics in a northern ecosystem. Proc. Natl. Acad. Sci. U.S.A. 70: 2745-2748. 
BOUCHARD, R., 1967. Étude d'un habitat d'été de l'original dans le Parc des Laurentides, 1964. Service de la Faune du Québec, Rapp. No 4. pp. 37-58.

COBUS, M. 1972. Moose as an aesthetic resource and their summer feeding behaviour. Proceedings of the North American Moose Conference and Workshop, 8: 244-275.

DALKE, P. D., R. D. BEEMAN, F. J. KINDEL, R. J. ROBEL, and T. R. WILLIAMS. 1965. Use of salt by elk in Idaho. J. Wildl. Manage. 29: 319-332.

DE VOS, A. 1958. Summer observations on moose behavior in Ontario. J. Mammal. 39: 128-139.

FIENBERG, S. E. 1970. The analysis of multidimensional contingency tables. Ecology, 51: 419-433.

FRASER, D. 1979. Sightings of moose, deer, and bears on roads in northern Ontario. Wildl. Soc. Bull. 7: 181-184.

FRASER, D., D. ARTHUR, J. K. MORTON, and B. K. THOMPSON. 1980. Aquatic feeding by moose Alces alces in a Canadian lake. Holarctic Ecol. 3: 218-223.

FRASER, D., and H. HRISTIENKO. 1981. Activity of moose and white-tailed deer at mineral springs. Can. J. Zool. 59: 1991-2000.

FRASER, D., and E. REARDON. 1980. Attraction of wild ungulates to mineral-rich springs in central Canada. Holarctic Ecol. 3: 36-40.

FRASER, D., and E. R. THOMAS. 1982. Moose-vehicle accidents in Ontario: relation to highway salt. Wildl. Soc. Bull. 10: 261-265.

GERRITZ, H. W. 1935. Digesting materials for calcium and phosphorus analysis. Ind. Eng. Chem. Anal. Ed. 7: 167.

HANSON, H. C., and R. L. JONES. 1976. The biochemistry of blue, snow, and Ross' geese. Illinois Natural History Survey, Special Publication No. 1.

HEBERT, D., and I. McT. COWAN. 1971. Natural salt licks as a part of the ecology of the mountain goat. Can. J Zool 49: 605-610.

JORDAN, P. A., D. B. BOTKIN, A. S. DOMINSKI, H. S. LOWENDORF, and G. E. BELOVSKY 1973. Sodium as a critical nutrient for the moose of Isle Royale. Proceedings of the North American Moose Conference and Workshop, 9: 13-42.

JOYAL, R., and B. SCHERRER 1978. Summer movements and feeding by moose in western Quebec. Can. Field-Nat. 92: 252-258.

PEEK, J. M., D. L. URICH, and R. J. MACKIE. 1976. Moose habitat selection and relationships to forest management in northeastern Minnesota. Wildl. Monogr. No. 48.

PETERSON, R. L. 1955. North American moose. University of Toronto Press, Toronto.

ROWE, J. S. 1972. Forest regions of Canada. Can. For. Serv. Publ. No. 1300.

STEWART, R. R., R. R. MACLENNAN, and J. D. KINNEAR. 1977. The relationship of plant phenology to moose. Saskatchewan Department of Tourism and Renewable Resources Technical Bulletin No. 3. 
TANKERSLEY, N. G. 1981. Mineral lick use by moose in the central Alaska range. M.Sc. thesis, University of Alaska, Fairbanks, AK .

WEEKS, H. P., JR. 1978. Characteristics of mineral licks and behavior of visiting white-tailed deer in southern Indiana. Am. Midl. Nat. 100: 384-395.

WEEKS, H. P., JR., and C. M. KIRKPATRICK. 1976. Adaptations of white-tailed deer to naturally occurring sodium deficiencies. J. Wildl. Manage. 40: 610-625. 